\title{
TERESA VILLAVERDE: MAKING OMELETS WITHOUT EGGS
}

\author{
Sharaf Rehman \\ Department of Communication \\ University of Texas Rio Grande Valley \\ One West University Boulevard, Brownsville, Texas, USA, 78520 \\ Sharaf.rehman@utrgv.edu
}

\begin{abstract}
Nearly 50 percent of the students graduating with degrees in film directing programs are women; nearly half of the film audiences around the globe are women; yet, women direct only 8 percent of the films. Like most other industries, men control by men the film industries. An opportunity to direct a film is hard to come by for men. It's even harder for women. However, when a woman breaks through the glass ceiling, the results are refreshingly satisfying - bringing new perspectives on the female experience and interpersonal relationships. The purpose of this paper is to bring to focus the work of a Portuguese film director, Teresa Villaverde. She began her film career as an actor in À Flor do Mar /Hovering over the Water (1986) and directed her first feature film, A Idade Maior (1991). Since then, she has directed more than a dozen films. For many of these, she has also doubled as writer, editor, cinematographer, and producer. Not only is she a prolific auteur director, her work has earned recognition at international film festivals. The paper describes her professional career and some of the themes she has tackled in her films, e. g., the homeless, the socially alienated, the abused and silenced and the economically unnecessary. Although working with small budgets, she has established herself among the most significant directors in Europe. Relying on existing interviews and reviews, the paper presents Villaverde as a role model for other young filmmakers pursuing careers in cinema.
\end{abstract}

Keywords: auteur cinema, European cinema, low-budget filmmaking, women film directors, cinema and society.

\section{Introduction}

Moving pictures arrived in Portugal in 1896, and the first cinema was built in 1904, however, filmmaking of any measure began with A Canção de Lisboa/Song of Lisbon (1933) directed by José Cottinelli Telmo that initiated the Golden Age of Portuguese cinema - an era that would last nearly two decades. In the year, 1942, Manoel de Oliveira directed his first full-length fictional film, Aniki-Bóbó (a rhyme from a children's game, akin to Eeny, meeny, miny, moe), a portrait of the street children of Oliveira's own hometown, Porto. Oliveira used non-professional youngsters to play the key roles. The story revolved around two young boys vying for the attention of a young girl. One of the boys 'is a bully and an extrovert; the other, shy and innocent. Although the film, upon its initial release, was a commercial failure, it has come to be regarded as a milestone. Its use of actual locations and real people brought forth a cinematic freshness that foreshadowed the Italian neorealism. For the next three decades, however, Oliveira was only able to secure funding for documentaries and occasional short films. He returned to feature films in 1971 with Past and Present and continued making films until 2014. Oliveira's sortie into realism has remained an important part of the Portuguese cinema, and filmmaking that evolved after the demise of the forty-year-long fascist control in 1974 bears the stamp of his seminal social-realism imagery of Aniki-Bóbó.

During the 1930s and the 1940s, the Salazar regime used the mass entertainment media for propaganda through the positive images of the Portuguese empire through narratives with cheerful people of Portugal, and tales where the ordinary people were the protagonists [1]. To promote cinema as an art, and Portugal as a modern nation on the international film scene, the regime initiated the Fundo Nacional do Cinema (National Cinema Fund) in 1948 and provided funding to several Portuguese filmmakers, and to those who wished to study abroad. The national fund also created the Portuguese Film Archive [2]. Nonetheless, during the 1950s, the Portuguese film industry was stagnant.

Portugal's Cinema Novo (New Cinema) that emerged in the 1960s bore strong similarities to the French New Wave, led by Jean-Luc Godard and Françoise Truffaut, and the Italian Neo- Realism heralded by Vittorio De Sica [3]. The result was an auteur cinema anchored in social realism 
trying to bridge the local films and the local audiences. Notable directors of the Cinema Novo were Fernando Lopes, Paulo Rocha, and António da Cunha Telles.

The arrival of democracy and the integration into the European Community allowed the Portuguese film industry an influence in the formation of policies and institutional changes that were to align Portugal with the other EU countries. Two distinct schools of filmmaking evolved during the 1990s. One group focused on making films for the national audiences and the other group addressed the subjects and themes that appealed to the judges at the international film festivals. The directors of the second group included Maria de Medeiros, Flora Gomez, Raúl Ruiz, Manoel de Oliveira, and Teresa Villaverde.

During the last three decades, less than 14 percent of the feature films have been directed by women in Portugal [4]. However, a change may be on the horizon for Portugal and its female filmmakers. For instance, at the 2016 Locarno Film Festival, 14 out of 200 films were from Portugal. Among these, Correspondences was directed by Rita Azevedo Gomes. In the short films' category, four out of 18 were Portuguese films - three of these were directed by women: An Aviation Field by Joana Pimenta, Friends after Dark by Rita Barbosa, and September by Leonor Noivo [5].

This paper will trace Villaverde's development as a director and discuss the important social and economic issues that she has repeatedly visited in her feature films.

\section{Aim of Research}

The focus' of this paper is Teresa Villaverde who has gained international recognition as an auteur filmmaker and claimed a permanent position at Venice, Cannes, Berlin, and other prestigious European film festivals where she has been a consistent contender or a winner as a writer-director since 1991.

\section{Teresa Villaverde}

Teresa Villaverde was born in Lisbon on May 18, 1966. Instead of following the film schools route, she opted for the old-fashioned, apprenticeship method. She began her career as an actress in À Flor do Mar /Hovering over the Water (1986), a film directed by João César Monteiro. She worked as an assistant to Paulo Rocha and collaborated as a co-writer with José Álvaro Morais and João Canijo. Fluctuating between acting jobs, and working behind the camera as continuity supervisor, co-scriptwriter, and assistant editor, she directed her first feature film, A Idade Major/ English Title: Alex, in 1991. Her films have consistently premiered in festivals such as Berlin and Cannes. She has also lectured on filmmaking in Portugal and Switzerland. Regrettably, due to restrains of space and time, this paper will only focus on her' feature-length narrative films and excludes her, equally important, documentary film work.

\section{Major Themes and Their Treatment in Villaverde's Films}

We will begin with her first feature film and follow the other films in their chronological order. This is also a logical approach to study the progression and development of an artist through their work. As mentioned earlier, her first feature film was A Idade Major/English Title: Alex, released in 1991. Alex is a story of a boy, whose father, Pedro, reluctantly goes to Africa during the turbulent colonial wars in the 1970s. For a while, Pedro writes to his son and his wife; the father and the son seem to have a close relationship. In the beginning, Pedro's letters to his wife and son are tender and loving. As the time passes, the letters become less frequent, bitter, and depressing. Eventually, the letters stop altogether. The mother and the boy fear that Pedro might have been captured, or worse. Another returning soldier informs Alex's mother that Pedro returned to Portugal several months ago. The boy, and his mother, abandoned by Pedro, have to fend for themselves, and the boy tries to carve his own identity.

The story parallels the story of Portugal after the end of fascism. The son's refusal to acknowledge his parents at the start of the movie suggests a nation's shame over its history and previous actions. Pedro's secretive return to his country and staying in hiding is a direct hint at a nation's embarrassment over its colonialist past. The Portuguese colonialism in Africa ended in 1974 as did the fascist rule, however, no filmmakers attempted to uncover the wounds received by the common 
people in Portugal or in Africa. Villaverde's directorial début with a topic so politically charged was a bold step. A quarter of a century later, she still continues to hold a mirror to her society presenting the serious issues that need serious treatment. She continues to pose uncomfortable questions the policymakers need to address and answer. In so doing, she is the voice of the people.

Her main characters display great capacity for enduring suffering and pain, and yet they are tenacious. Often, they are on the verge of nervous breakdowns and suffer from identity crises and abandonment. Yet, they survive. The confusion of the youths of the underprivileged classes in another frequently recurring theme in her work. Grasping the essence of Alex's confusion and disorientation, The New York Times described the film as "an intriguing exercise in glumness that never states what is in the back of its mind" [6].

Her next film, Três Irmãos/Two Brothers, My Sister (1994) is a dark and powerful story of three brothers and their sister, Maria. Her blind father has a tendency to become violent after drinking. He becomes physically abusive towards his wife who is eventually driven to suicide. The four siblings share an apartment in Lisbon with two other men. The group is living a life of purposelessness. It is a portrayal of the lost youth during the 1990s going through the motions of living without any plans for the future or concerns for the past. The characters don't even seem to care about the present. One day, they decide to go their separate ways. As a dutiful daughter, Maria tries to pull the family together. She ends up stabbing her boss as he attempts to rape her. Actress, Maria de Medeiros, who played the unassuming sister and daughter, received the Best Actress Award at Venice International Film Festival.

Villaverde's next production, Os Mutantes/The Mutants (1998) was screened at the 1998 Cannes Film Festival. Just as a father in A Idade Major/Alex abandoned his son, the Portuguese juvenile system abandons a group of teenagers in Os Mutantes. The film tells a bleak story about the neglected street-children, their exploitation, abuse, and eventual descent into lives of violence and crime. Based on her research on the runaways and the children of the street, Villaverde had planned the project as a documentary with the intention of using actual children that slip through the cracks in the system of the state-run facilities. The authorities, fearing criticism, declined her proposal. Villaverde turned the project into a fictional narrative.

Os Mutantes/The Mutants was immediately controversial in Portugal, inspiring a nationwide debate over reform of the nation's youth programs. In a documentary style, the film tells the story of three homeless teenagers, Andrea (Ana Moreira), Pedro (Alexandre Pinto), and Ricardo (Nelson Varela) who hustle, rob and steal for their survival. Andrea is pregnant with Ricardo's child. The two boys, Ricardo and Pedro are exploited by the pornography industry. The boys are constantly exposed to merciless brutality. The victimized homeless children, in time, turn into ruthless and violent individuals engaging in senseless violence, rape, and murder. The film raises an important question: How can a nation allow such atrocities on its children that are its future?

In a masterfully constructed scene, Villaverde shows the emotional strain Andrea experiences after she has abandoned her newborn in a public toilet. Andrea sits in a café across the street and watches as the baby is discovered and handed over to the authorities. The arrival of the ambulance and the police vehicles are only suggested through the sound effects. The camera remains on the young mother's face. In addition to presenting the gritty reality of the homeless in Lisbon, Os Mutantes/The Mutants is also a bold commentary on the failure of integration of the Africans in Portugal, and their rejection by the Portuguese society. The white Portuguese and the descendants of the African colonies share only the language, not the place [7]. Os Mutantes/The Mutants won Villaverde the New Director's Showcase Award at the Seattle International Film Festival in 2000.

Thematically, Os Mutantes/The Mutants is linked to two of Villaverde's later films - Transe/ Trance (2006, and Cisne/Swan, 2010, as all three deal with horrifying violence [8]. However, chronologically, Villaverde's' next feature film was Água e Sal/Water and Salt (2001).

The film is set in a small seaside town. Ana (Galatea Ranzi), her husband Mario (Joaquim de Almeida), and their daughter Criança (Clara Jost) are staying in the resort town for the summer. The couple's relationship seems strained. The husband decides to take the daughter back to their home in the city, leaving his wife to concentrate on her work on a humanitarian art project involving images of people that have been denied their freedom. Alone, Ana is drawn into the mundane 
occurrences of life. She runs into some old acquaintances as well as some total strangers. Água e Sal/Water and Salt makes a point that people don't just play one role in their lives. That people have different parts to play in different circumstances. An individual is more than just one person and as life happens, like a forceful tide, it takes people with it and throws them into different directions. What Ana thought was important, becomes the background. New developments take the center stage. One hopes that, in the end, all the pieces will fall into their right places. In real life, all that happens is that the pieces simply fall. Some may blame it on destiny, others on gravity. I suspect that the later would be Villaverde's choice. The film was shown at the Orizzonti section of the 68th Venice International Film Festival.

In her next film, Transe/Trance (2006), Villaverde returns to another universal topic: exploitation of the powerless by those with power. This time, it's human trafficking that blankets from Russia to Germany and into Italy. Sonia (Ana Moreira), a young woman struggling to make a living in St. Petersburg, decided to migrate to Western Europe in hope of a better life. She acquires a job as an unskilled worker at a car dealership. She is tricked by a co-worker and kidnapped. She is abused, and sold into sex slavery, first in Germany, and later to a brothel in Italy. She makes several attempts at escape but is unsuccessful. In Italy, not being able to speak the language, she is isolated to the extent of mute segregation. The beating and abuse she endures after every failed escape attempt leaves her baffled and more confused. Eventually, she is bought by a rich man for his two sons. The elder son rapes her; the younger brother looks on. The younger sibling, who seems to be mentally challenged, allows Sonia to escape. She is recaptured and brought back to the rich man's house, and as her punishment, she is made to endure further humiliation and bestiality. In the final scene, she meets another man, perhaps a rescuer, perhaps another human trafficker. The exchange that takes place is vaguely repetitive of what we saw earlier in the film. The viewer can only assume that Sonia has temporarily lost her grip on reality and perhaps lost her mind. In the very final shot, she lays down on the bed. If it is in surrender to the man's lust, or to rest and regain her strength, the viewers have to decide for themselves. The screen goes black. Transe/Trance won a Special Jury Award at the 2007 Lecce Festival of European Cinema.

The rebellious streak in the three women, Andrea in Os Mutantes, Maria in Três irmãos, and Sonia in Transe reminds one that these women despite all the adversities have not lost the spark of will and self-perseverance. As Jahn [9] suggests, these women force the viewers to acknowledge their existence in a world where they have loved, lived, and suffered.

The global economic recession of the late 2000s impacted the Portuguese film industry as the funds for the Portuguese Film Institute evaporated, leaving the Portuguese cinema in a state of limbo [2]. There was a gap of five years between Transe/Trance and Villaverde's next film, Cisne/ Swan (2011). Faced with financial limitations, Villaverde created her own production company, Alce Filmes, in 2010 and undertook to producer her own film, arguing that by controlling the production she could direct most of the funds to the making of the film.

Vera (Beatriz Batarda) is a successful singer/musician on a concert tour. Her final performance is to be in Lisbon, her hometown. From a number of potential companions, she has chosen Pablo (Miguel Nunes) to keep her company through her sleepless nights. Pablo is melodramatic, has no family, but wants to have one. Vera has no ties and seems to want none. She also has a relationship with another man, Sam (Israel Pimenta) who lives away from her and can only love her from a distance. Vera loves Sam. He shows up at her house and wants to stay there but without her. He asks her to leave because he wants to be close to her things but not close to her. Vera is saddened but agrees, leaving him in the house. Pablo is taking care of a young boy, Alce (Sérgio Fernandes). Alce is sexually abused by an adult, and he kills his abuser. Vera does not judge the boy. She understands that his actions were justifiable, and sensing that something has to be done to protect Alce, she takes him under her wing.

Giving only the barebones to the audience, Villaverde has created an aesthetic delight blending the calm of the Iberian sunshine and blue skies with the restless bewilderment and confusion of the main characters. Vera and Sam represent a male-female relationship suffering from a relational dialectic tension: autonomy versus connection [10]. On the surface, it is a happy ending. Happier and more optimistic than Villaverde had offered in her previous work. How long will Vera, Sam, and Alce be able to live together, there's no telling. The three may be happy for a long time. On the 
other hand, the arrangement may fall apart within a short time. Interpersonal relationships do not come with warranties. Villaverde makes no promise.

Her next film, Colo (2017) returned to the issue of the disintegration of the family. A theme she explored in A Idade Major/Alex (1991), Os Mutantes/The Mutants (1998), Água e Sal/Water and Salt (2001), and Cisne/Swan (2011).

Colo shows the crumbling of a contemporary family weighed down by unemployment and the economic depression - a family where the mother (Beatriz Batarda) works long hours trying to hold onto two jobs, the unemployable father (João Pedro Vazis) who feels worthless, and is reduced to desperate acts such as eating food he finds in the garbage and trying to mug an old acquaintance, and a teenage daughter (Alice Albergaria Borges) who tries to come to terms with the harsh realities of poverty. Unable to pay the electricity bill, the family must rely on candles for light. The unemployed father spends his time on the roof staring at the horizon which offers no hope for future. The mother returns home exhausted from working double shifts, the mother hardly has the energy to communicate with her husband or the teen-aged daughter who too keeps her secrets to herself and is reduced to ducking the bus fare when going to school. The three begin to assume new roles as their relationships to each other shift. It is as if the economic impacts a person's character, and new (sometimes not so pleasant) dimensions come to surface. The ray of light in the film comes in the form of the news that the wife's best friend is pregnant - a new life, a new hope. Using anguish and tension, Villaverde pushes her three characters to their limits stretching the boundaries of cinema and the audiences' imagination. Relying on symbolism and suggestion, and without spelling out too many details, Villaverde has created an experience that is seductive, mystifying and thought-provoking in equal portions. The film is reminiscent of the inescapable desperation that comes from hopelessness and degradation of unemployment and lack of resources that was vividly explored in the neorealism of Vittorio De Sica's Bicycle Thief (1948) and Umberto D (1952).

The film was nominated for the Best Picture honor at the 2017 Berlin International Film Festival and won at Bildrausch Filmfest Basel.

\section{Conclusions}

At the premiere of Colo (2017) in Berlin, Villaverde echoed her concern over the threat to globalization that is posed by the nationalistic movements and Brexit, i.e., the protectionism by commenting, "With unemployment and everything like that, people get lost and then comes someone like Donald Trump or, in Europe, ... these new right-wing people like Marine Le Pen. There are many countries that have had a long democratic tradition and to our surprise, we see the return of right-wing parties across Europe - we thought we'd never see this again" [11]. Such controls infringe upon the artistic freedom, creativity, and the ability to criticize political systems. Many European nations have paid the price of such controls during the dictatorial regimes in Italy and Germany, and the Soviet control of the Eastern European countries. Auteur cinema and protest films are genres of rebellion against totalitarianism. Artists in these camps demand the right to comment on the conditions and connect with their characters that must survive in those conditions. Villaverde insists on the freedom to venture into personal cinema. A case in point: In Água $e$ Sal/Water and Salt (2001), the young girl who plays Ana's daughter Criança (Clara Jost) is Villaverde's daughter and at the time of the production, Villaverde was going through some difficult separation and child custody issues. On the surface, the film could be considered personal. However, Villaverde holds that unless she can find something that connects her to the main character, she is unable to write the character or make the film, thus, all her films are personal [12].

The ability to connect with a character is of the essence. Many film directors have visited the topic of the runaway children or restless teenagers (Blackboard Jungle, 1955; Rebel Without a Cause, 1955; East of Eden, 1955; Splendor in the Grass, 1961), and many have explored the sexual exploitation of women (BUtterfield 8, 1960; Of Human Bondage, 1964; Lilya 4-Ever 2002; Promised Land, 2004; Field of Mudan, 2004; Human Trafficking, 2005. Countless films have focused on male-female relationships (The Private Lives of Elizabeth and Essex, 1939; Two Women, 1960; The Lion in Winter, 1968; Carnal Knowledge, 1971; Who's Afraid of Virginia Wolf? 1966; Streetcar Named Desire, 1951). In all of the above cases, the degradation of the victimized children and wom- 
en is perceived from the male point-of-view. The question asked has been: How does a man deal with the runaways, the troubled youths, and the exploited women? Villaverde has turned the tables and addressed these issues from the female perspective. Her stories are the stories of the children that are abandoned by their parents: Alex in A Idade Major, Andrea in Os Mutants, Pablo in Cisne, and Alice in Colo are all neglected by their parents. These films show the struggle and perspective of the unwanted and the cast-away.

Her films, when dealing with male-female relationships provide fresh insights into the 'female' experience in a male-dominated world. Thus, a stressed and neurotic wife is not a husband's problem; she is driven to such emotional state by the male. The neglected children that turn to juvenile delinquency were not born with those tendencies, the neglect and abandonment deliver them to the street and the life of crime leading to their destitution and misfortune. Villaverde is a reformist (although she may not admit to being one) and uses her medium for social comment rather than mere entertainment.

Her films are intentionally paced to move slowly. Instead of cutting every six seconds (as is the gospel according to Hollywood), she holds her shots for longer durations allowing the actors to take their'time, and the audience to absorb the full content of each shot. She raises important social questions but does not offer answers to all. Some are answered, others remain unanswered inviting the viewers to draw their own conclusions and interpretations. Her films are not for the passive audience. Her cinema requires active participation.

Villaverde has held that the strength of her country's auteur cinema is in the freedom it allows its artists. Filmmakers are free to pursue their ideas. Even with limited resources and low budgets, the Portuguese filmmakers have become experts in making omelets without eggs. Undisputedly, Teresa Villaverde is the master chef in the kitchen.

\section{References}

[1] Macedo, I., Bastos, R., Cabecinhas, R.; Epstein, M., Orsitto, F., Righi A. (Eds.) (2017). Representation of dictatorship in Portuguese cinema. In: TOTalitarian ARTs: The visual arts, fascism(s) and mass-society. Ch. 13. Newcastle upon Tyne: Cambridge Scholars Publishing. 251-283

[2] Baptista, T. (2010). Nationally correct: The invention of Portuguese cinema. Portuguese Cultural Studies, 3, 3-18.

[3] Liz, M. (2017). Portugal's global cinema: Industry, history and culture. London: I. B. Tauris, 288.

[4] Pereira, A. C. (2016). The woman-filmmaker: From art for art's sake to a differentiation aesthetic. Covilha: Universidade da Beira Interior, 357.

[5] Morais, R. (2016). Locarno: How modern Portuguese cinema is uniting the past and the present.” IndieWire. Available at: http://www.indiewire.com/2016/08/locarno-film-festival-2016-portuguese-cinema-1201716158/ Last accessed: 28.02.2018

[6] Holden, S. (1992). Reviews/Film festival; A Portuguese boy's view of war and separation. The New York Times.

[7] Ferreira, C. O.; Rego, C., Brasileiro, M. (Eds.) (2014). Imagining Migration: A Panoramic View of Lusophone Films and Tabu (2012) as a Case Study. Migration in Lusophone Cinema. Ch. 1. New York: Palgrave Macmillan, 17-40. doi: 10.1057/9781137408921_2

[8] Bittencourt, E. (2012). To accept the unacceptable: Reflections of three films by Teresa Villaverde. Senses of Cinema, 65. Available at: http://sensesofcinema.com/2012/feature-articles/to-accept-theunacceptable-reflections-on-three-films-by-teresa-villaverde/

[9] Jahn, P. (2017). Teresa Villaverde - Fragiler punk. Bildrausch Film fest Basel. Available at: http://www.bildrausch-basel.ch/archiv/festivalarchiv/bildrausch-2017/teresa-villaverde-fragiler-punk/

[10] Baxter, L. A. (1990). Dialectical Contradictions in Relationship Development. Journal of Social and Personal Relationships, 7 (1), 69-88. doi: 10.1177/0265407590071004

[11] Martin, M. (2017). Unemployment in Portuguese movie 'Colo' is one reason for populism, director says. Entertainment News. Available at: https://uk.reuters.com/article/us-berlin-filmfestival-colo/unemployment-in-portuguese-movie-colo-is-one-reason-for-populism-director-says-idUKKBN15U2IX

[12] Bittencourt, E. (2012). One day, the swan sang this with its wings: An interview with Teresa Villaverde. Senses of Cinema, 65. http://sensesofcinema.com/2012/feature-articles/one-day-the-swan-sangthis-with-its-wings-an-interview-with-teresa-villaverde/ 